
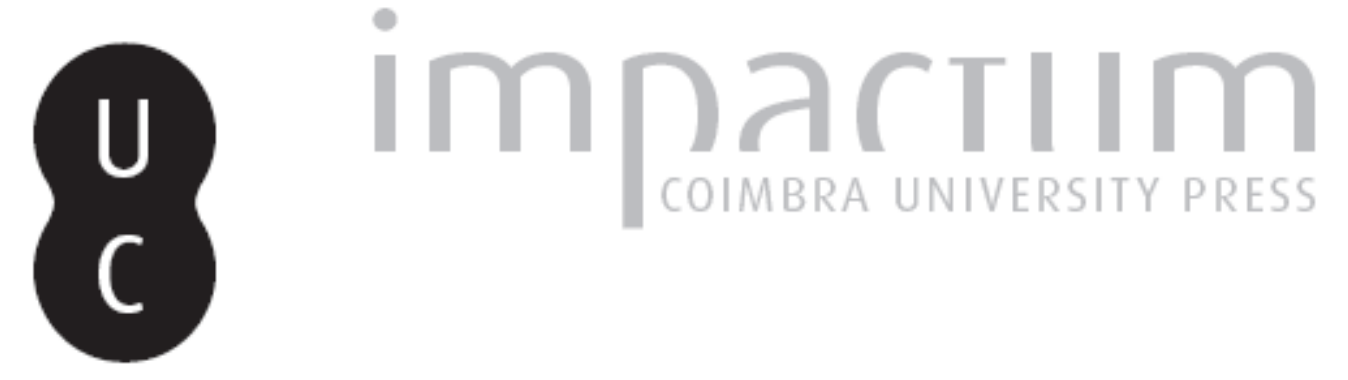
Poderão as pessoas comuns cobrir conflitos: o potencial das tecnologias dos novos
media

Autor(es): $\quad$ Steiner, Linda

Publicado por: Imprensa da Universidade de Coimbra

URL persistente:

URI:http://hdl.handle.net/10316.2/43152

DOI:

DOI:https://doi.org/10.14195/2183-6019_4_4

Accessed : $\quad$ 26-Apr-2023 14:47:33

A navegação consulta e descarregamento dos títulos inseridos nas Bibliotecas Digitais UC Digitalis, UC Pombalina e UC Impactum, pressupõem a aceitação plena e sem reservas dos Termos e Condições de Uso destas Bibliotecas Digitais, disponíveis em https://digitalis.uc.pt/pt-pt/termos.

Conforme exposto nos referidos Termos e Condições de Uso, o descarregamento de títulos de acesso restrito requer uma licença válida de autorização devendo o utilizador aceder ao(s) documento(s) a partir de um endereço de IP da instituição detentora da supramencionada licença.

Ao utilizador é apenas permitido o descarregamento para uso pessoal, pelo que o emprego do(s) título(s) descarregado(s) para outro fim, designadamente comercial, carece de autorização do respetivo autor ou editor da obra.

Na medida em que todas as obras da UC Digitalis se encontram protegidas pelo Código do Direito de Autor e Direitos Conexos e demais legislação aplicável, toda a cópia, parcial ou total, deste documento, nos casos em que é legalmente admitida, deverá conter ou fazer-se acompanhar por este aviso.

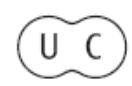


revista de comunicação,

jornalismo e espaço público

$\angle$

Periodicidade

Semestral

Imprensa da Universidade de Coimbra Coimbra University Press

\section{mediapolis}

comunicação e transformações sociais

communication and social transformations 


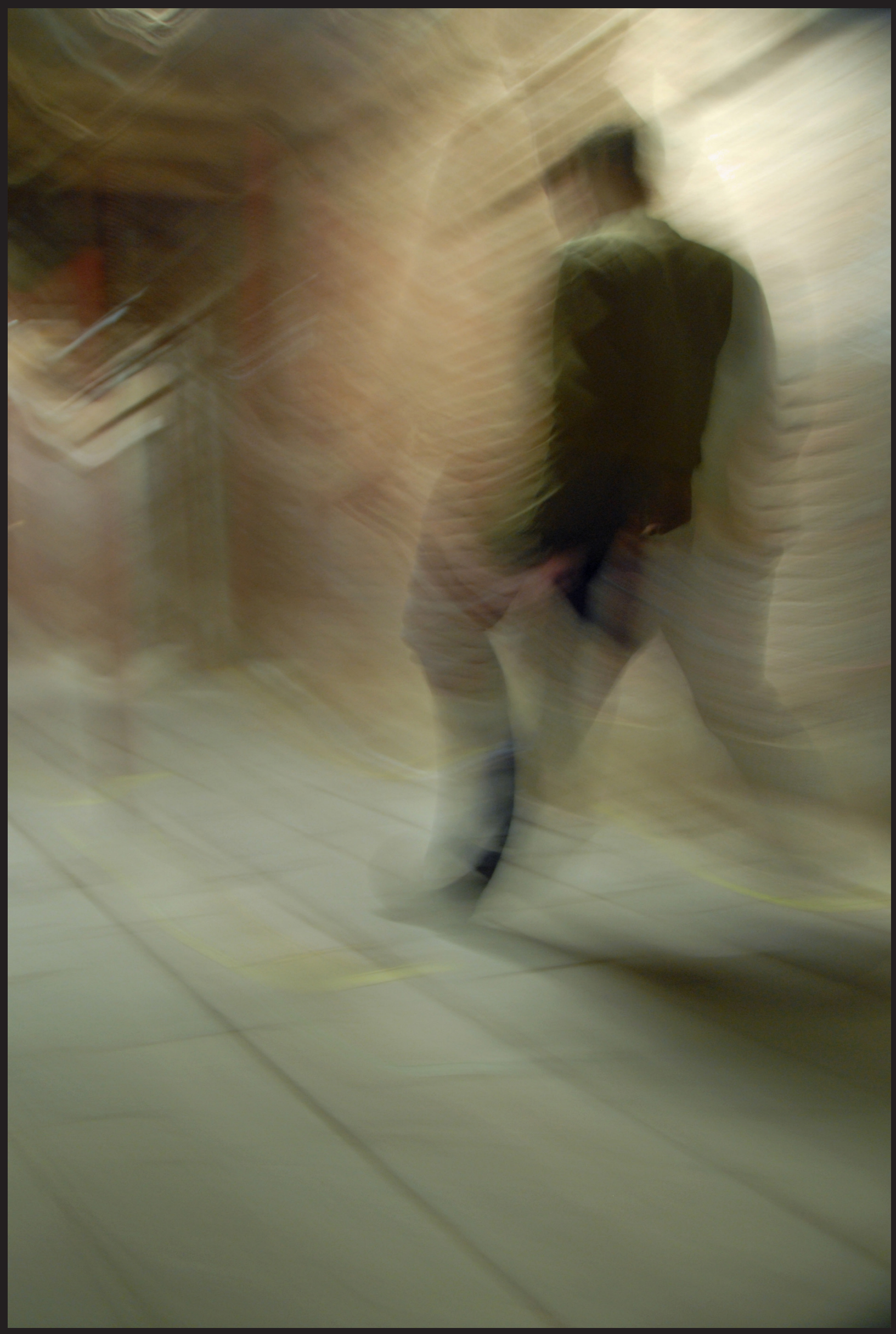




\title{
Poderão as pessoas comuns cobrir conflitos? $O$ potencial das tecnologias dos novos media*
}

\author{
Can citizen witnesses report on conflict: \\ the potential of new media technologies
}

\section{Resumo}

O envolvimento de não-profissionais na produção de notícias tem aumentado drasticamente, em especial através da utilização de novas tecnologias e aplicações: telefones por satélite, Skype, Twitter, YouTube, blogging, som e imagem em streaming e redes sociais. Mas o jornalismo cidadão é controverso, particularmente no que diz respeito à cobertura de guerra. Neste artigo, considero em que medida as pessoas sem formação em jornalismo, mas 'armadas' com ferramentas de reportagem, podem relatar guerras e conflitos. Começo por sumariar os desafios desta prática para as organizações de notícias que tentam cobrir guerras e conflitos internacionais e descrever vários projetos que ajudam freelancers e cidadãos. Tendo em conta os perigos para uns e outros, sugiro, depois, algumas intervenções viáveis.

Palavras-Chave: Jornalismo cidadão, novas tecnologias mediáticas, cobertura de guerra e conflitos.

\section{Abstract}

Non-professionals are increasingly involved in reporting news, especially by using new technologies and applications: satellite phones, Skype, Twitter, YouTube, blogging, streaming sound and picture, and social networking. But citizen journalism is controversial, especially regarding war reporting. I take up the extent to which people without journalism training but 'armed' with reporting tools can report on war and conflict. I first summarize the challenges to legacy news organizations trying to cover international war and conflicts and describe several projects to assist freelancers and citizens. Given the dangers to freelance and citizen war reporters, I suggest some workable interventions.

Keywords: Citizen journalism, new media technologies, war and conflict reporting.
* Traduzido para português por Rita Basílio deSimões (rbasilio@fl.uc.pt),Faculdade de Letras da Universidade de Coimbra/Centro de Estudos Interdisciplinares do Século XX (CEIS20) da Universidade de Coimbra 


\section{Introdução}

Quer académicos quer cidadãos têm vindo a manifestar interesse em saber em que medida poderão as pessoas comuns participar efetiva e produtivamente na recolha de notícias. Naturalmente, nem todos os cidadãos praticam atos de jornalismo. Mas muitos fazem-no. Em consequência, cada vez mais as organizações de notícias criam oportunidades para os cidadãos, não apenas comentarem ou sugerirem histórias, mas também produzirem textos e imagens visuais em tempo real. Algumas destas organizações poderão fomentar esse envolvimento, porque os cidadãos o querem ou exigem e/ou os editores acreditam que esse compromisso irá encorajar apoio financeiro. Outras estarão talvez mais seriamente preocupadas em favorecer os processos democráticos. Certo é que várias experiências no âmbito da participação de não-profissionais na recolha, elaboração, análise e divulgação de notícias estão a provocar uma enorme efervescência global no jornalismo. Novas tecnologias e aplicações - telefones por satélite, Skype, Twitter, Facebook e YouTube, blogging, gravação e streaming de som e imagem e redes sociais
- permitem aos cidadãos contestar o monopólio dos jornalistas na definição, produção e disseminação de notícias. Esta dinâmica adquire força à medida que as tecnologias em causa se tornam mais baratas e mais fáceis de dominar e de adaptar. Tudo isto altera não somente o pensamento, como também as práticas do ecossistema jornalístico.

Contudo, os jornalistas profissionais raramente partilham o aparente entusiasmo das organizações de notícias pelas parcerias de marketing com os cidadãos. Regra geral, os jornalistas expressam preocupações com a veracidade, a confiabilidade e até mesmo a simples precisão do conteúdo produzido por cidadãos. Esta sua resistência ou hostilidade para com a participação dos cidadãos na cobertura jornalística tem sido por vezes entendida como mero patrulhamento de autoproteção de fronteiras - isto é, um interesse corporativo semelhante em proteger postos de trabalho -, em vez de receio pela qualidade das notícias e muito menos preocupação genuína com a segurança dos cidadãos-testemunhas. Sem a pretensão de mencionar todos os contextos de jornalismo cidadão, trato neste artigo da versão mais extrema da questão de saber quem pode fazer o quê. Ou seja, considero em que medida as pessoas sem formação em jornalismo, mas 'armadas' com ferramentas de reportagem, podem relatar sobre guerra e conflito. Após esboçar brevemente os desafios desta prática para as organizações de notícias que tentam cobrir conflitos internacionais, ofereço um roteiro aleatório e incompleto de experiências de jornalismo cidadão em todo o mundo. Em seguida, descrevo os riscos e perigos específicos da cobertura de guerra independente e baseada em cidadãos. Concluo, depois, mencionando algumas experiências e intervenções que podem ser viáveis.

Em primeiro lugar, deve reconhecer-se a relevância das novas formas de guerra, nomeadamente com a participação de atores não-estatais, que não tomam parte de convenções e normas internacionais. Entre outros aspetos, isto significa que os jornalistas estão em risco, não apenas de sofrerem danos colaterais, como também de serem diretamente visados. Em 2008, um correspondente e três membros iraquianos da equipa da Rádio Pública Nacional [dos Estados 


\section{Introduction}

Both scholars and citizens have recently expressed interest in how and to what the extent citizens can effectively and productively participate in news-gathering. Naturally, not all citizens want to commit acts of journalism. But many do. As a result, news organizations are increasingly opening up opportunities for citizens not merely to comment on stories and suggest stories, but also to submit texts and visual images in real time. Some news organizations may be inviting such involvement merely because citizens want or demand this and/or because publishers believe this engagement will encourage financial support. Others are perhaps more seriously concerned with democratic processes. Several experiments that turn on the participation of non-professionals in collecting, reporting, analyzing, and disseminating news are provoking enormous global ferment in journalism. New technologies and applications - satellite phones, Skype, Twitter, Facebook and YouTube, blogging, recording and streaming sound and picture, and social networking
- enable citizens to challenge journalists' monopoly to define, produce, and disseminate news. The dynamic gains strength as the relevant technologies become cheaper and easier to learn and adapt. All of this alters not merely the thinking but also the practices of the journalism ecosystem.

But professional journalists rarely share the apparent enthusiasm of news organizations for marketing partnerships with citizens. Professional journalists express concerns about the overall truthfulness, reliability, even sheer accuracy of citizen-produced content. Their resistance or outright hostility to citizen participation in news reporting has sometimes been read as merely self-protective boundary patrolling - that is, a guild-like interest in protecting jobs - rather than concern for the quality of news, much less sincere concern for the safety of citizen witnesses. Without claiming to mention all contexts of citizens-journalism, in this article I address the most extreme version of the question of who can do what. That is, I take up the extent to which people without journalism training but "armed" with reporting tools can report on war and conflict. After briefly sketching out the challenges to legacy news organizations trying to cover conflicts around the world, I offer a somewhat random and incomplete tour of citizen journalism experiments around the world. Then, I describe the particular risks and dangers of freelance and citizen-based war reporting. I conclude by mentioning some experiments and interventions that may be more workable.

To begin, one must acknowledge the relevance of new forms of warfare, including by non-state actors who are not party to international conventions and norms. Among other things, this means that journalists are at risk not merely as collateral damage but by being directly targeted. In 2008 an National Public Radio correspondent and three Iraqi NPR staff members narrowly escaped an assassination attempt in Baghdad after a hidden bomb exploded underneath their armored BMW, which was parked, along with a second NPR "chase car" while they were interviewing a kebob shop's owners. An Iraqi army officer had received a tip about the "sticky" bomb while the journalists were 
Unidos da América] (NPR) escaparam por pouco a uma tentativa de assassinato, em Bagdad, na sequência da explosão de uma bomba escondida debaixo do BMW blindado que usavam, estacionado ao lado de uma segunda viatura de 'perseguição' da NPR, enquanto entrevistavam os proprietários de uma loja de kebab. Um oficial do exército iraquiano recebeu uma dica sobre a bomba 'acoplada', enquanto os jornalistas estavam dentro do espaço comercial. Alguns anos antes de ser morta na Síria, a repórter de guerra do Sunday Times Marie Colvin perdeu um olho durante a cobertura no Sri Lanka, quando um atacante lhe arremessou uma granada, sabendo, segundo a própria afirmou mais tarde, ser ela uma jornalista. Em 2010, num discurso publicado postumamente, Colvin (2012) referiu: "Nunca foi tão perigoso ser correspondente de guerra, porque o jornalista tornou-se um dos principais alvos na zona de combate".

Parte inferior do formulário

Colvin estava deveras correta. A reportagem de guerra é cada vez mais perigosa. O Clube de Correspondentes Estrangeiros do Japão dá conta de 71 jornalistas mortos enquanto cobriam a guerra do Vietname, entre 1962 e 1975. O Fórum da Liberdade contabiliza 17 jornalistas mortos durante a cobertura da Guerra da Coreia e 68 durante a cobertura da Segunda Guerra Mundial. Todavia, entre 2003 e 2009, cerca de 139 correspondentes de guerra, a maioria deles iraquianos, foram mortos no Iraque.

Estes perigos fazem encarecer a cobertura de conflitos. O valor despendido com o envio de repórteres (estrangeiros) para lugares, tais como o Iraque, inclui US $\$ 3.000$ [dólares dos Estados Unidos] de treino em ambientes hostis (condução defensiva, observação do perigo, medicina de emergência); e um seguro pessoal de US $\$ 1.500$ por dia. Um profissional de apoio recebe pelo menos US\$300 por dia; o seu trabalho é altamente arriscado, sendo que necessitam (e nem sempre conseguem) de equipamento de segurança e de seguros. Os custos fixos podem incluir coletes à prova de balas, orçados entre US\$ 1.500 a US\$ 1.800 a unidade; um veículo blindado, que custa US $\$ 100.000$; e a locação e manutenção de habitação e escritórios seguros (fortificados). Isto além de salários, transporte, seguro dos repórteres, assistência médica e eventuais tratamentos para PTSD [Posttraumatic stress disorder (transtorno de stresse pós-traumático)]. Em 2008, o New York Times, a exceção que confirma a regra, gastou aproximadamente US $\$ 3$ milhões por ano com o seu escritório fortificado de Bagdad, onde trabalhavam quatro repórteres, dois fotógrafos e 100 funcionários iraquianos, todos armados (Mnookin, 2008).

$\mathrm{O}$ risco, o custo e o aparente desinteresse do público por notícias de conflito também podem ser contrastados com a facilidade de obtenção, produção e atração de audiências por notícias sobre escândalos e celebridades. Não é, pois, de admirar que as redes de televisão tenham reduzido significativamente o número e a dimensão das suas redações no estrangeiro; os jornais de elite e as principais cadeias de jornais encerraram os espaços que mantinham. Em 2015, por exemplo, a cadeia McClatchy fechou o seu quinto e último escritório internacional. 
inside. A couple of years before she was killed in Syria, the Sunday Times war reporter Marie Colvin lost an eye while covering Sri Lanka when an attacker threw a grenade at her, knowing, she said, that she was a journalist. In a 2010 speech posted posthumously Colvin (2012) said: "It has never been more dangerous to be a war correspondent, because the journalist in the combat zone has become a prime target."

Colvin was only too correct. War reporting is increasingly dangerous. The Foreign Correspondents Club of Japan lists 71 journalists killed while covering the Vietnam war 1962-75. The Freedom Forum lists 17 journalists killed covering the Korean War and 68 during World War II. But between 2003 and 2009, some 139 war correspondents, most of them Iraqi, were killed covering Iraq.

These dangers make conflict reporting expensive. The expense incurred in sending (foreign) reporters to places like Iraq included a $\$ 3,000$ hostile environment training (defensive driving, spotting danger, emergency medicine); and a personal security detail at $\$ 1,500$ a day per person. A fixers gets at least $\$ 300$ a
In 2008 the

\section{New York Times,}

the exception

that proves

the rule, spent

approximately

$\$ 3$ million a year

on its heavily

fortified Baghdad

bureau, staffed by

four reporters, two

photographers,

and 100 Iraqi

employees day; the work is highly risky for them so they need (but do not always get) security equipment and insurance. Fixed costs might include bulletproof vests at $\$ 1,500$ to $\$ 1,800$ each; an armored vehicle costing $\$ 100,000$; and renting and maintaining safe (fortified) housing and offices. Besides reporters' pay, transportation, insurance, there might be medical care and therapy for PTSD. In 2008 the New York Times, the exception that proves the rule, spent approximately $\$ 3$ million a year on its heavily fortified Baghdad bureau, staffed by four reporters, two photographers, and 100 Iraqi employees, all armed (Mnookin, 2008).

The risk, the cost, and apparent disinterest of audiences in news of conflict may also be contrasted to the ease of getting, producing, and attracting audiences for news about scandal and celebrity. No wonder, then, that TV networks have significantly reduced the number and size of their bureaus; elite newspapers and major newspaper chains have closed their foreign bureaus. In 2015, the McClatchy chain, for example, closed its last five foreign bureaus. 


\section{Experiências mundo fora}

Muito tem sido feito no campo da dinâmica e capacidades tecnológicas que estimulem ou permitam esforços amadores para relatar conflitos, locais e internacionais. Ao longo do tempo, câmaras ou telefones capazes de gravar som e imagem tornaram-se mais baratos, mais acessíveis a mais pessoas, menores e, portanto, mais portáteis. O software que permite às pessoas fazer o upload, partilhar e descarregar é mais fácil de utilizar, ainda que não o seja necessariamente para projetar e instalar. Claro que em alguns lugares com tradições orais ancestrais, especialmente em comunidades rurais, baixa alfabetização e igualmente baixas taxas de penetração da Internet, os jornalistas cidadãos ainda operam por rádio e telefonia. É o caso do CGNet Swara, ou Voice [portal online baseado na voz, acessível por telefone móvel], opera em Chhattisgarh, no centro da Índia tribal, onde a penetração da Internet é inferior a $1 \%$, comparativamente com a penetração da telefonia móvel, que é muito alta. Há muito que as questões tribais no Chhattisgarh são ignoradas.
Os jornalistas regionais e nacionais, não podendo falar as línguas locais ou contratar pessoas que o fazem, mantêm, no entanto, preocupações com os violentos confrontos na área, envolvendo insurgentes políticos. A tecnologia de resposta de voz interativa do CGNet Swara permite aos habitantes locais enviar e receber mensagens de telefonia móvel na sua própria língua.

A ideia original de que os repórteres nacionais poderiam aceder ao CGNet Swara para obter informações para desenvolver as suas próprias histórias não funcionou (Chadha \& Steiner, 2015). Mas os utilizadores do portal - estudantes treinados, líderes comunitários e ativistas - podem tanto ouvir e gravar relatos de locais como notícias aprovadas (verificadas).

No Uganda, onde os programas de rádio são as principais fontes de notícias, as emissoras radiofónicas estão a usar uma plataforma de software [online], TRAC FM, e a sua experiência em formação, para produzir um jornalismo de dados e, simultaneamente, estimular os ouvintes a tornarem-se participantes ativos no debate público. Durante os debates ao vivo em emissoras de rádio parceiras, os ouvintes podem enviar um SMS gratuito em resposta a perguntas lançadas; os resultados dos inquéritos são atualizados instantaneamente para que os talk-shows os possam usar. A TRAC FM encara a sua missão como sendo de promoção do debate informado entre cidadãos, jornalistas e líderes políticos e da transparência e prestação de contas.

No Quénia, a plataforma de acesso livre Ushahidi, vencedora de uma bolsa MacArthur, permite aos utilizadores partilharem informações sobre desastres ou emergências de forma rápida e em tempo real, via SMS, Twitter e RSS. A Ushahidi, que significa testemunho ou testemunha em Swahili, foi desenvolvida no início de 2008 durante um blackout dos media, na sequência das controversas eleições no Quénia. Um conjunto de voluntários usaram o software para agregar, visualizar e partilhar relatos de testemunhas oculares tanto de esforços em nome da paz como em nome da violência. Atualmente, os utilizadores instalam este software livre nos seus próprios servidores para, durante uma crise, partilharem boletins de informação curtos, relatos de testemunhas, ou fotografias, num mapa online ou 


\section{Experiments}

\section{around the world}

Much has been made of the dynamics and technological affordances that encourage or enable amateur efforts to report on local and international conflict. Over time, cameras or phones able to record sound and picture have become cheaper more and accessible to more people, and getting smaller and thus more portable. Software enabling people to upload, share, and download is easier to use, albeit not necessarily to design and install. Of course, in some places enduring oral traditions, especially in rural communities, and low literacy and low rates of Internet penetration, mean that citizen journalists must still operate by telephony and radio. CGNet Swara, or Voice, operates in Chhattisgarh, in central India, where Internet penetration is less than one percent but mobile phone penetration is very high. Moreover, Chhattisgarh's tribal issues had been long ignored: Regional and national journalists cannot speak local languages or hire fixers who do, and are nervous about violent clashes in the area involving

\section{During live debates} on partner radio

stations, listeners

can submit a free

SMS in response

\section{to questions}

political insurgents. CGNet Swara's interactive voice response technology enables villagers to send and receive cell phone messages in their own language. The original idea that national reporters would access CGNet Swara to get information to develop for their own stories has not worked out (Chadha \& Steiner, 2015). But users - trained students, community leaders and activists - can both record local news and listen to approved (verified) stories.

In Uganda, where radio talk shows are major news conduits, radio stations are using a software platform TRAC FM, and its hands on training, to produce data-driven journalism and also to enable radio listeners to become active participants in public debate. During live debates on partner radio stations, listeners can submit a free SMS in response to questions; the poll results are instantly updated for talk-show hosts to use. TRAC FM sees its mission as promoting informed debate among citizens, journalists and political leaders, and promoting transparency and accountability.

In Kenya, the MacArthur-winning open source platform Ushahidi enables users quickly and in real time to share 
cronograma. Simultaneamente, podem usá-lo para notícias fora desse contexto. Em qualquer dos casos, para os jornalistas profissionais, a plataforma significa a possibilidade de utilizarem as informações compartilhadas pelos cidadãos na produção das suas próprias notícias. Syria Tracker, por exemplo, trabalhou com a Ushahidi para criar um mapa interativo das mortes na Síria, com informação recolhida de múltiplos bancos de dados e relatos de diferentes públicos.

No Brasil, a Mídia Ninja começou essencialmente como um movimento estudantil vocacionado para organizar eventos culturais independentes, tendo vindo, no entanto, a expandir-se e a transformar-se numa universidade, partido político e sistema financeiro alternativos. O movimento lançou a Mídia Ninja (ninja, neste contexto, representa "narrativas independentes, jornalismo e ação") como o seu braço de comunicação, cobrindo originalmente eventos nas favelas e pequenos protestos que de outra forma não seriam levados ao conhecimento público. Rapidamente, o coletivo começou a fazer uso de telefones móveis para transmitir imagens de violência policial contra manifestantes e para curar esse e outro material recolhido online ou enviado para o grupo. A organização, que se orgulha da sua rede copiosa de voluntários colaborativos e cultura descentralizada, tem contado com doações, em detrimento de publicidade. Todavia, esta forma de crowdfunding tem provocado controvérsia entre os jornalistas cidadãos. Em particular, por a organização ter decidido aceitar o donativo de George Soros, visto como pondo em causa a sua independência e valores não comerciais e anticapitalistas.

A Mídia Ninja granjeou um estatuto considerável com a cobertura dos protestos de 2013, desencadeados um pouco por todo o Brasil; várias grandes cadeias de rádio, televisão e meios impressos salientaram o mérito dos seus materiais e até mesmo a sua primazia, visto reconhecerem estarem dependentes da versão policial, por serem menos capazes de se aproximarem dos manifestantes e de outros outsiders (Watts 2013). Vale, no entanto, a pena notar que os repórteres ninja têm sido sujeitos a balas de borracha, gás lacrimogéneo, pedras e spray de pimenta; estes cidadãos têm sido ameaçados verbalmente e, em algumas ocasiões, detidos.

Dois jornalistas profissionais brasileiros lançaram mão do crowdfunding para lançar outra organização sem fins lucrativos destinada a produzir jornalismo de investigação promotor dos direitos humanos e do debate democrático. A Pública [Agência de Reportagem e Jornalismo] não é jornalismo cidadão, mas um corpo editorial formado pelos crowdfunders, que escolhem as temáticas e as histórias que são publicadas online (http://www. apublica.org/Reportagem-Publica), com uma licença Creative Commons. A Pública encoraja os outros media e os seus próprios leitores a "furtarem as suas histórias" e a republicarem-nas.

O Hong Kong In-Media, fundado em 2004, é uma plataforma de acesso aberto, que oferece notícias criadas por cidadãos repórteres voluntários, que recebem formação e estágios em produção noticiosa; os cidadãos comuns também podem carregar na plataforma conteúdo crowdsourced e comentários. Ainda que direcionada para a distribuição de notícias e opiniões sobre Hong Kong, a In-Media tem vindo, ao longo do tempo, a cobrir 
and crowdsource information from SMS, Twitter, and RSS feeds about a disaster or emergency. Ushahidi, Swahili for "testimony" or "witness," was developed in early 2008 during a media blackout that followed Kenya's election controversies. Volunteers used the software to aggregate, visualize and share eyewitness accounts of both peaceful efforts and violence. Now, users install free software on their own servers to share short bursts of information, eyewitness accounts, or photos on an online map or timeline during a crisis, and they can use it for non-crisis news. Either way, legacy journalists can also use citizen-shared information for their own news stories. Syria Tracker, for example, worked with Ushahidi to create an interactive map of deaths in Syria by amassing data from multiple databases and crowdsourced reports.

In Brazil, Mídia Ninja began largely as a student movement to organize independent cultural events, but expanded into an alternative university, a political party and financial system. The movement launched Mídia Ninja (ninja stands for, in Portuguese, "independent narratives, journalism and action") as its communications arm, first, covering events in the favelas and small protests otherwise unreported. But then the collective began using mobile phones to broadcast images of police violence against protesters, and to curate material gathered from images posted online or sent to the group. Mídia Ninja prides itself on its capillary network of collaborative volunteers and decentralized culture. The group had been relying on donations in lieu of advertising, but funding remains controversial among the citizen journalists. Crowd-funding drew backlash from members, but Ninja Media's willingness to accept funding from George Soros was criticized as contradicting its independence and anti-capitalist non-commercial values.

Mídia Ninja gained considerable status with its coverage in 2013 of social protests throughout Brazil; several major broadcast and print news outlets acknowledged using its materials, and even being outperformed by it, since mainstream organizations are more reliant on the police version and are less able to get close to protestors and other outsiders (Watts 2013). But it's worth noting that ninjas report being subjected to rubber bullets, tear gas, stones, and pepper spray; they have been verbally threatened and occasionally detained.

Two Brazilian professional journalists used crowd-funding for launch another non-profit to produce investigative journalism promoting democratic debate and human rights. A Pública is not citizen journalism but an editorial board formed by the crowd-funders chooses the subjects and the stories are published online (http://www.apublica.org/Reportagem-Publica) with a Creative Commons license. A Pública encourages readers and other media "to steal their stories" and re-publish them.

Hong Kong In-Media, founded in 2004 , is an open platform carrying reporting from citizen reporter volunteers, who get training and internships in news production; citizens can also to upload crowdsourced content news and commentaries. HK In-Media focuses on Hong Kong news and opinions, but over time it has more actively covered social-political issues in Greater China and Southeast Asia. It only deletes articles or commentaries in the highly rare cases of hate speech or commercial spam; such deletions require the prior approval of more 
mais ativamente questões político-sociais na Grande China e Sudeste Asiático. Só em casos raros são eliminados artigos ou comentários, nomeadamente quando é usado discurso de ódio ou spam comercial; esta arbitragem requer a aprovação prévia de mais de metade dos membros da $I n-M e-$ dia. Financiada através de membros e de receitas provenientes do trabalho com ONG's e fundações, a plataforma recusa doações por parte de partidos políticos e corporações.

No Afeganistão, embora a maioria das pessoas possua telefones móveis, poucas utilizam plataformas de media sociais. Além disso, a deslocação de jornalistas profissionais a áreas tribais ou remotas é considerada perigosa. O [website] Paiwandgah permite que os afegãos utilizem media sociais, SMS e tecnologia móvel para distribuir notícias (o seu interesse original foi a cobertura das eleições afegãs, mas, atualmente, encoraja a produção de conteúdo diverso) em Inglês, Pashto e Dari (Yazid 2014). Parte do projeto Impassion Afghanistan, Paiwandgah permite que qualquer pessoa que viva no Afeganistão se registe como jornalista cidadão; podem fazer perguntas aos jornalistas cidadãos utilizadores em todo o mundo. Tendo como modelos a Global Voices, a CNN iReport e, especialmente, a CG SwaraNet, na Índia, e a Tribal News Network, no Paquistão, a maioria dos relatos de cidadãos reunidos no Paiwandgah são enviados por SMS ou telefone e, menos frequentemente, via os media sociais, principalmente o Facebook. Os participantes carregam os seus relatos e os jornalistas profissionais confirmam a veracidade desse conteúdo; as informações que não podem ser confirmadas são publicadas com a menção "não-verificada". A todos é disponibilizada formação no uso de tecnologia digital para produção de notícias, embora esta não seja exigida. De realçar, no entanto, que o projeto passou por uma série de problemas e de abusos, incluindo trolls e pessoas que espalharam rumores falsos. Ainda assim, e de acordo com um funcionário, a BBC Farsi tem usado os jornalistas cidadãos do Paiwandgah como correspondentes e outros meios de comunicação têm citado o seu conteúdo. ${ }^{1}$

1 http://bit.ly/2dpvC2W.
Algumas destas plataformas afirmam operar a uma escala global. A Oximity distribui globalmente conteúdos produzidos por escritores individuais, jornalistas independentes, artistas, organizações e redes independentes. Esses conteúdos seguem por vários canais para os leitores, tendo por base os seus interesses, o seu idioma e localização. Estes, por sua vez, elegem os artigos com maior qualidade (substantivos, atuais, baseados em fatos, transparentes), dão feedback sobre eles e partilham-nos nos media sociais, podendo ainda adicionar-lhes informações. De salientar também que a plataforma fornece ferramentas para proceder à personalização e tradução para inglês, francês, alemão, árabe, russo e espanhol dos artigos existentes. Os produtores de conteúdos podem optar por cobrar aos leitores pelas suas histórias; se assim for, estabelecem uma taxa específica individual. 
than half of HK In-Media's members. Funded through members and revenue from work with NGOs and foundations, it accepts no donations from corporations or political parties.

In Afghanistan, most people have mobile phones but few use social media platforms, and for professional journalist to enter many tribal and/or remote areas is dangerous. Paiwandgah enables Afghans to use social media, SMS, and mobile technology to offer news (its original interest was coverage of Afghan elections but it now encourages more diverse content) in English, Pashto, and Dari (Yazid 2014). Part of the project Impassion Afghanistan, Paiwandgah allows anyone living in Afghanistan to register as a citizen journalist; readers around the globe can ask citizen journalists questions. With Global Voices, CNN iReport and especially CG SwaraNet in India and the Tribal News Network in Pakistan as its models, most Paiwandgah citizen reports are submitted by SMS or phone, and, less often, social media, mostly Facebook. Staffers upload the reports and professional journalists confirm the veracity of the crowdsourced reports; reports that cannot be verified are
Oximity's platform

provides tools for

customization,

\section{and translation}

into English,

French, German,

Arabic, Russian

and Spanish published and tagged as "unverified." Training in the use of digital technology for reporting is available but not required. It has had a range of problems and abuses, including trolls and people who have spread false rumors. Nonetheless, according to a staffer, BBC Farsi has used Paiwandgah citizen journalists as stringers, and other news outlets have quoted them. ${ }^{1}$

Some platforms claim to operate on a global scale. Oximity globally distributes crowd-curated content produced by individual writers, independent journalists, artists, organizations and independent networks. It goes to readers across multiple channels based on interests, language and location. Readers vote on which articles are high-quality (substantive, newsworthy, fact-based, transparent), give feedback, and share on social media. Readers can add further information to an existing article. Oximity's platform provides tools for customization, and translation into English, French, German, Arabic, Russian and Spanish. Content creators can opt to charge readers for stories; if so, they set the fee for the individual story.

1 http://bit.ly/2dpvC2W. 


\section{Os perigos para os diferentes tipos de repórteres de guerra}

Qualquer cobertura de guerra é arriscada. Mas fazê-lo como freelancer é especialmente perigoso. Em 2016, de acordo com o Committee to Protect Journalists [Comité de Proteção de Jornalistas], 42\% dos jornalistas mortos durante tiroteios ou combates eram freelancers. Desde 1992, cerca de $29 \%$ de todos os jornalistas mortos em tiroteios ou combates eram igualmente freelancers; também desde 92, 46\% dos jornalistas mortos na Síria trabalhavam neste regime. ${ }^{2}$ Atualmente, a Síria parece ser o lugar mais perigoso para trabalhar, de acordo com a Reporters Sans Frontières (RSF) [Repórteres Sem Fronteiras]. Em particular, para os jornalistas-cidadãos (pessoas que não têm formação profissional em media, nunca trabalharam no jornalismo e são independentes ou estão ligadas a algum centro local) e internautas, ou seja, cidadãos-jornalistas que divulgam o seu trabalho na internet.

2 https://cpj.org/killed/in-combat.php.
No contexto da cobertura de guer$\mathrm{ra}$, os freelancers correrem mais riscos e os riscos crescentes para os freelancers são os dois lados de uma mesma moeda. Desde a Guerra do Vietname, em geral, os repórteres podem evitar ser envolvidos e, simultaneamente, desde que tenham dinheiro, chegar às zonas de guerra por conta própria. Algumas mulheres foram para o Vietname comofreelancers, porque as organizações com as quais tinham vínculos laborais se recusaram a enviá-las. No presente, os idealistas, aventureiros ou repórteres novatos também vão para as zonas de guerra. Isto permite que os editores de notícias, que deixaram de ter correspondentes em tempo integral e muito menos escritórios estrangeiros, podem escolher o conteúdo que desejam produzido por blogueiros e jornalistas freelancers mochileiros, a quem não oferecem suporte, seguro ou salário. O único risco de usar freelancers decorre de não se saber necessariamente em quem ou em que confiar destas fontes alternativas da informação. Ayman Oghanna, um fotógrafo freelancer iraquiano de origem britânica, que cobre atualmente o Iraque e que trabalha sobretudo mediante contratação, afirma ter jurado nunca se deslocar à Síria sem ser no âmbito de uma missão atribuída por uma organização noticiosa que pague o seu seguro. "Várias revistas de prestígio disseram: 'Entre e, quando estiver fora de perigo, ficaremos com o que tiver" (apud Hammer, 2014). Oghanna recusou sempre que as suas exigências mínimas não foram cumpridas. Muitos freelancers, no entanto, aceitaram esses termos.

Nos últimos anos, muitos freelancers foram sequestrados - talvez por não poderem pagar ou, mesmo podendo, não usarem guarda-costas, motoristas armados e não viajarem em grupo. De entre os tomados como reféns, vários não puderam contar com o auxílio de empresas de media na negociação da sua libertação. Alguns executivos, porém, quiseram envolver-se no problema, assumindo a causa dos freelancers sequestrados. Foi o caso de David G. Bradley, proprietário da Atlantic Media, que publica diversas revistas de informação respeitadas. Fê-lo, em primeiro lugar, em 2011, quando Clare Gillis, freelancer em trabalho para o Atlântico, e James Foley, foram capturados por 


\section{The dangers to war reporters of various sorts}

Any war reporting is dangerous. Freelancing is especially dangerous. In 2016, according to the Committee to Protect Journalists, $42 \%$ of journalists killed in crossfire or combat were freelancers. Since 1992, some 29 per cent of all journalists killed in crossfire or combat were freelancers; 46 per cent of journalists killed in Syria since 1992 were freelancers. ${ }^{2}$ Now Syria seems to be the most dangerous place, according to Reporters Sans Frontieres (Reporters Without Borders/RSF), especially for citizen-journalists (people who lack professional media training, never previously worked in journalism and who are either independent freelancers or affiliated with some local center) and netizens, i.e., citizen-journalists disseminating their work via the Internet.

In the context of war coverage, the rise of risk-taking freelancers and the risks to freelancers are two sides of a coin. Since the Vietnam War, for the most part, reporters can avoid

2 https://cpj.org/killed/in-combat.php. embedding and, if they had the money, get themselves to war zones on their own; some women went to Vietnam as freelancers because their news organizations refused to send them. Now people who are idealists, adventurers, or novice reporters also go to war zones. So news editors who no longer have full-time foreign correspondents, much less foreign bureaus, can pick and choose the content they want from bloggers and freelance backpack journalists to whom they do not provide support, insurance, or salary. The only risk of using freelancers comes from not necessarily knowing who or what to trust from these alternate sources of information. Ayman Oghanna, a British-born Iraqi freelance photographer who primarily works on contract and is now covering Iraq, says that he vowed never to go into Syria without having an assignment from a news outlet that covered his insurance. "A number of prestigious magazines said, 'Go in, and when you're out of danger we'll take what you have"" (quoted in Hammer, 2014). Oghanna refused when his minimal requirements were not met. But many freelancers accepted those terms.

In recent years, several freelancers have been kidnapped - perhaps because they cannot afford or otherwise do not use body-guards, armed drivers, and don't travel in groups. And for many freelancers taken hostage, no news organization is negotiating for their release. A few executives have stepped up to the plate. David G. Bradley, the owner of Atlantic Media, which publishes several prominent news magazines, has taken up the cause of kidnapped freelancers, first, in 2011, when Clare Gillis, a freelancer for The Atlantic, and James Foley, were captured by soldiers loyal to Muammar Qaddafi and held 44 days. In 2012 Theo Padnos (aka Peter Theo Curtis) was kidnapped and handed over to al-Qaeda almost as soon as he entered Syria as a freelancer, apparently intending to write about Austin Tice, a former U.S. Marine and apparently the first freelancer to disappear in Syria. Tice was working for The Washington Post, CBS and others news outlets when he was abducted and four years later is still missing. Padnos, who had earned a doctorate in comparative literature and knew five languages, and written a book about Islamic extremism, was released almost two years later, in 2014, with Bradley's help. 
soldados leais a Muammar Kadafi e mantidos em cativeiro durante 44 dias. Voltou a fazê-lo em 2012. Nesse ano, Theo Padnos (aka Peter Theo Curtis) foi sequestrado e entregue à Al-Qaeda assim que entrou na Síria como freelancer, com a intenção aparente de escrever sobre Austin Tice, um ex-marine dos EUA e, supostamente, o primeiro freelancer a desaparecer na Síria. Tice trabalhava para o The Washington Post, a CBS e outros media quando foi sequestrado. Quatro anos depois, continua desaparecido. Padnos, que possui um doutoramento em literatura comparada e conhece cinco línguas, escreveu um livro sobre o extremismo islâmico, lançado quase dois anos após o sucedido, em 2014, com a ajuda de Bradley.

A equipa de Bradley não teve, no entanto, o mesmo êxito em proteger outros jornalistas independentes, nomeadamente James Foley e Steven Sotloff. Tendo sido libertado da Líbia, Foley foi capturado na Síria, em 2012 , enquanto trabalhava como freelance para a Agence France-Presse e a GlobalPost. Esta última uma start-up que, originalmente, pretendia utilizar repórteres profissionais, mas acabou por recorrer a freelancers de baixo custo para a produção da maior parte das suas notícias. A GlobalPost afirma ter-se mantido próxima de Foley e ter-lhe exigido que obtivesse treino em ambientes perigosos. Sustenta também que, apesar disso, Foley entrou sozinho na Síria, depois de rejeitar uma oferta de emprego da organização, na América do Sul (Hammer, 2014). Já a France-Presse diz não ter discutido com Foley as suas futuras movimentações, nem lhe ter pedido para ir a uma área particular (apud Hammer, 2014). Foley acabou por ser decapitado em agosto de 2014, pelo ISIS [Islamic State of Iraq and Syria (Estado Islâmico)]. Steven Sotloff, por seu lado, um jornalista americano-israelense que trabalhou para a Time, Christian Science Monitor, Foreign Policy e revelou a história de Benghazi na CNN, foi sequestrado na Síria em 2013 e decapitado também pelo ISIS cerca de 13 meses depois.

As dimensões de género destes perigos merecem igualmente ser realçadas. Há muito que a inexistência de paridade no jornalismo freelance se verifica. E as tendências apreendidas (socializadas) pelas mulheres em relação ao idealismo, ao interagirem com a sua determinação em cobrir a guerra tal como os homens o fariam (mesmo quando os homens não o fazem), só agravam os perigos. $\mathrm{O}$ problema do idealismo tornou-se evidente, em 2014, aquando da morte de uma fotojornalista francesa, Camille LePage, de 26 anos, que cobria o conflito na República Centro-Africana. O último tweet de Lepage dava conta de que a repórter viaja de moto com a milícia anti-balaka. O presidente francês apelidou sua morte de "assassinato", sugerindo que Lepage foi um alvo deliberado. Lepage trabalhou para várias ONGs, mas o seu trabalho no Sul do Sudão e no CAR tinha sido amplamente utilizado, inclusive pela $\mathrm{BBC}, \mathrm{Al}$ Jazeera e prestigiados jornais dos EUA e da Europa. Em 2013, a jornalista explicou como se sentia "chocada" e "indignada" com a pouca cobertura da realidade no Sul do Sudão:

\footnotetext{
“Também percebi o que era a agenda dos media e como tantas histórias sérias estavam ausentes das manchetes, simplesmente porque não se enquadravam nessa agenda ou nos interesses
} 
But Bradley's team was unsuccessful on behalf of others, most prominently, James Foley and Steven Sotloff. Having been released from Libya, Foley captured in Syria in 2012 while working freelance for the Agence France-Presse and GlobalPost. The latter is a start-up that originally intended to use reporters on retainer, but then using low-paid freelancers to provide most of its reporting. GlobalPost maintained a closer relationship with Foley, and required Foley to take a hazardous environments training course, but says Foley went into Syria on his own after rejecting its offer of a staff job in South America (Hammer, 2014). Agence France-Presse said it neither discussed movements with Foley nor asked him to go to a particular area (quoted in Hammer, 2014), Foley was beheaded in August 2014 by ISIS. Steven Sotloff, an American-Israeli journalist who had worked for Time, Christian Science Monitor, Foreign Policy, and broke the Benghazi story on $C N N$, was kidnapped in Syria in 2013, and beheaded by ISIS about 13 months later.

Moreover, it's worth pointing out the gendered dimensions of these
Women have

long been

disproportionate

among free-lancer

journalists hazards. Women have long been disproportionate among free-lancer journalists. And women's learned (socialized) tendencies toward idealism interacts with women reporters' determination to undertake war reporting just as men do (or even when men won't) compound the danger. The problems of idealists are evident in the 2014 killing of a French photojournalist Camille LePage, age 26, while she was covering the conflict in the Central African Republic. Lepage's last tweet said she was travelling with the anti-balaka militia by motorbike. France's president called her death "murder" and suggested that Lepage was targeted deliberately. Lepage worked for several NGOs but her South Sudan and CAR work had widely used, including by the BBC, Al Jazeera and prestigious papers in the US and Europe. In 2013 she explained how she was "shocked" and "outraged" by the little coverage of South Sudan:

\footnotetext{
"I also realized what the media agenda was, and how so many serious stories were missing from the headlines simply because they don't fit within that agenda, or the
} 
dos anunciantes. Não posso aceitar que as tragédias das pessoas sejam silenciadas unicamente porque ninguém pode ganhar dinheiro com elas. Decidi fazê-lo eu mesma, lançando alguma luz sobre elas, independentemente do resto." (Jones, 2013)

Com efeito, as críticas às mulheres que se envolvem na cobertura de guerra como independentes (e às vezes também às que o fazem munidas de um vínculo institucional, como demonstraram os comentários antipáticos dirigidos a Lara Logan, correspondente estrangeira da CBS, sexualmente agredida enquanto cobria os protestos de 2011 no Cairo) adotam, com frequência, um tom sexista. A freelancer canadense Amanda Lindhout, por exemplo, cobria a situação na Somália quando foi sequestrada em 2008, juntamente com um fotojornalista australiano (e ex-namorado), Nigel Brennan, e o seu tradutor e motorista somali. Lindhout tinha experiência de trabalho em zonas de guerra, na África, no Iraque e no Afeganistão. Durante os 15 meses que antecederam o resgate por US\$
600.000 (cerca de metade da quantia originalmente exigida), Brennan foi espancado. Lindhout foi torturada, espancada e violada repetidamente.

Margaret Wente (2013), do Globe and Mail, enfatizou a propósito que a sua simpatia por Lindhout, vítima de violações coletivas, fome e doenças, foi "temperada pelo fato de as pessoas narcisistas e imprudentemente ingénuas, como Lindhout, serem muitas vezes os seus piores inimigos". Para Wente, Lindhout era uma empregada de mesa "altamente fotogénica", cuja história pouco tinha a ver com o jornalismo. Noutro contexto, duas mulheres repórteres perguntaram a Lindhout se achava ter sido violada por ser "bonita".

Certamente que o idealismo e entusiasmo de Lindhout e Lepage não eram piores do que o de outros freelancers, embora, no seu caso, tivessem sido desafortunadas. Em abril de 2016, por exemplo, Kevin Patrick Dawes, um fotógrafofreelancer coreano-americano, mantido em cativeiro na Síria durante quase quatro anos, foi liberado com a ajuda da Rússia e da República Checa. Os jornalistas que o conheceram durante a cobertura dos conflitos na Líbia e na Síria expressaram aparentemente sérias preocupações acerca do seu aventureirismo em zonas de guerra, apelidando o seu comportamento de irracional e errático (Gladstone \& Callimachi, 2016). Tendo vendido tudo o que tinha para adquirir um bilhete de entrada na Síria, Dawes tentou reunir $\$ 28.000$ por um drone que sobrevoasse o Norte da Síria; conseguiu atrair $\$ 30$. 0 verdadeiro problema de Dawes era o seu "estado mental precário", principalmente a paranoia: "Dawes nunca deveria aproximar-se de uma zona de guerra. Se não fosse pelo espírito de amadorismo promovido pela internet e pela rede de conexões que ela abriu, provavelmente, ele teria ficado em casa" (Harkin, 2016).

No seu blog, Christopher Allbritton descreve o seu périplo atribulado pelo Curdistão iraquiano, em 2002, à procura de histórias ou "o que alguns poderiam chamar de 'à procura de problemas'. Em 2003, voltou para a guerra, "tornando-se o primeiro jornalista blogueiro". Mais tarde, descreveria esse período como "emocionante e perigoso - em que a cobertura jornalística foi surpreendentemente 
advertising company's interests. I can't accept that people's tragedies are silenced simply because no one can make money out of them. I decided to do it myself, and bring some light to them no matter what." (Jones, 2013)

Indeed, the criticism of women who undertake freelance war reporting (and full-time, for that matter, as unsympathetic reporting on CBS chief foreign correspondent Lara Logan, sexually assaulted literally while covering protests in Cairo in 2011 demonstrated) often adopts a sexist tinge. Amanda Lindhout, a Canadian freelancer, for example, was covering Somalia when she was kidnapped in 2008, along with an Australian photojournalist (and former boyfriend) Nigel Brennan and their Somali translator and driver. Lindhout had reported from war zones in Africa, Iraq and Afghanistan. During the 15 months before they were ransomed for $\$ 600,000$ (about half of the original demand), Brennan was beaten. Lindhout was tortured, beaten, and repeatedly raped.

The Globe and Mail's Margaret Wente (2013), however, emphasized that her sympathy for Lindhout, having endured gang rape, starvation and disease was "tempered by the fact that narcissistic, recklessly naive people like Ms. Lindhout are often their own worst enemies. They bring trouble not only on themselves, but on their families, their helpers and fixers and the governments that get involved in rescuing them." For Wente, Lindhout was a "highly photogenic" cocktail waitress whose story had little to do with journalism. Two woman reporters asked Lindhout whether she thought she was raped because she was "pretty."

But surely Lindhout and DePage's idealism and enthusiasm was not worse than that of other freelancers, although they were unluckier. In April 2016, for example, Kevin Patrick Dawes, a Korean-American freelance photographer held in Syria for nearly four years, was released with the assistance of Russia and the Czech Republic. Journalists who met him while covering the conflicts in Libya and Syria apparently expressed serious worries about his war-zone adventurism, and called his behavior irrational and erratic (Gladstone \& Callimachi, 2016).
Having sold everything he had in order to scrape money for a ticket to get into Syria, Dawes attempted to crowd-fund $\$ 28,000$ for a drone to fly over northern Syria; he attracted $\$ 30$. Dawes's real problem was his “precarious mental state," primarily paranoia: "Dawes should never have been near a warzone. If it wasn't for the internet's spirit of can-do amateurism and the web of connections it opened up, he probably would have stayed at home" (Harkin, 2016).

On his blog, Christopher Allbritton describes stumbling around Iraqi Kurdistan in 2002, looking for stories, "or what some might call 'looking for trouble."” In 2003 he returned for the war, "becoming the Web's first fully reader-funded journalist-blogger." He later described that period as "thrilling and dangerous — and surprisingly easy reporting." In 2004, he returned to Iraq for TIME Magazine. "And it's a good thing, too," he said that he had TIME's security apparatus to back him up and an editor who would miss him if he failed to show up. In a September 13, 2005 post, Allbritton mentioned getting emails from many aspiring foreign correspondents who wanted to cut their 
fácil.” Em 2004, regressou ao Iraque em nome da TIME. "E é igualmente uma coisa boa", afirmou, relatando que pôde contar com o aparelho de segurança da revista e de um editor, que daria por falta dele se não aparecesse. A 13 de setembro de 2005, Allbritton tornou público que recebia emails da parte de muitos aspirantes a correspondentes estrangeiros, que dariam os dentes para ir até ao "lugar mais perigoso do mundo para trabalhar como jornalistas". Muito embora dissesse entender o sentimento, advertiu: "neste momento, acho que é um curso de ação imprudente".

Já no novo milénio, várias novas empresas foram lançadas em resposta à escassez de correspondentes e à emergência da "gig economy"3 de freelancers. A Worldcrunch, lançada em 2011, obtém os direitos sobre histórias produzidas por jornais estrangeiros, tradu-las para inglês - usando, com frequência, jornalistas freelancers poliglotas -, vende-as a media anglo-saxónicos dispersos pelo mundo à semelhança do que fazem as agências

3 Nota da tradutora: mercado baseado no uso de profissionais sem vínculo laboral e de freelancers. de notícias e dissemina-as no seu próprio website. Do lado das organizações sem fins lucrativos, o Pulitzer Center on Crisis Reporting produz jornalismo original para o seu próprio website, mas também faz parcerias com operadores de imprensa e radiotelevisão. $\mathrm{O}$ Pulitzer Center trabalha com escolas e universidades públicas para usarem o jornalismo que promove, incentivando o envolvimento e discussão nas grandes questões globais.

Os websites BuzzFeed e Vice estão a prometer disseminar mais notícias internacionais. Em 2013, o BuzzFeed contratou o ex-chefe do departamento de Moscovo do The Guardian para criar escritórios estrangeiros e contratar repórteres em tempo integral. Aparentemente, o BuzzFeed mantém um conselheiro de segurança e recusa pedidos de missões na Síria. Contudo, estes websites também podem explorar freelancers. Uma denúncia recente sobre como a organização Vice atrasa o pagamento a freelancers, ou não lhes paga de todo, começou desta maneira: "Numa era do jornalismo em que os freelancers se habituaram a ser tratados como as engrenagens descartáveis da produção de notícias, a Vice parece ocupar uma liga própria" (Schwartz, 2016). Uma jornalista francesa disse que o soube imediatamente, ao receber o pedido para que arranjasse entrevistas com ex-recrutas do ISIS a título gracioso. "Mas se eu fosse uma jornalista de 23 anos, jovem e a morrer de vontade de trabalhar para a Vice", sustentou, "provavelmente, ter-me-ia matado para conseguir tudo o que queriam. E isso é um problema." Dos 25 freelancers contatados por Yardena Schwartz, cuja passagem pela organização foi negativa, apenas três classificaram a sua experiência como positiva - e dois desses três também se queixaram de remunerações baixas ou pagamentos atrasados. Assim que o Columbia Journalism Review publicou a história, a Vice enviou um memorando prometendo fazer melhor.

Várias startups entretanto surgidas - algumas aguentando-se durante mais tempo do que outras - permitem que os freelancers do século XXI e as organizações noticiosas se encontrem mutuamente. A maioria dos novos negócios foi apoiada por capital de risco e lançada com fins lucrativos. NewsFixed e GRNlive, atualmente denominados de PayDesk, são fabricantes 
teeth in "the most dangerous place in the world to work as a journalist." $\mathrm{He}$ understood the sentiment. "But at this time, I think it's an unwise course of action," he said.

Meanwhile, in the new millennium several start-ups launched in response to the dearth of foreign reporting and the emerging "gig economy" of freelancers. Worldcrunch, launched in 2011, obtains the rights to foreign newspaper stories, translates them into English - often using multilingual freelance journalists - and sells them to English-language media around the world through client news organizations, and runs them on its own website. On the nonprofit side, the Pulitzer Center on Crisis Reporting produces original journalism for its own website but also partners with print and broadcast news outlets. The Pulitzer Center works with public schools and colleges to use the journalism it sponsors to encourage engagement and debate on the big global issues.

The on-line sites BuzzFeed and Vice are promising to run more international news. In 2013, BuzzFeed hired The Guardian's former Moscow bureau chief to build foreign bureaus, including by hiring full-time reporters.
Worldcrunch,

launched in

2011, obtains the

rights to foreign

newspaper stories,

translates them

into English

- often using

multilingual

freelance

journalists
BuzzFeed apparently keeps a security adviser on retainer and has turned down requests from correspondents asking for Syria assignments. But such sites may be exploiting freelancers, too. A recent expose on how Vice delays payment to freelancers, or does not pay them at all, began this way: "In an era of journalism in which freelancers have grown accustomed to being treated like disposable cogs of news production, Vice appears to be in a league of its own" (Schwartz, 2016). One French journalist said she immediately saw through Vice's request that she arrange, without pay, interviews with former ISIS recruits. "But if I was a 23-year-old, young, budding journalist who's dying to work for Vice," she said, "I probably would have killed myself to get everything they wanted. And that's a problem." Out of 25 freelancers contacted by Yardena Schwartz, whose own Vice experience was negative, only three rated their experience freelancing for Vice as positive-and two of the three likewise complained about either delayed or low payment. Once the Columbia Journalism Review published the story, Vice sent a memo promising to do better. 
de encontros entre empresas de televisão e de rádio e freelancers que, normalmente, assumem o custo e o risco de ir para o estrangeiro. Trabalhar para vários operadores pode auxiliar os freelancers a adaptarem o seu trabalho a múltiplas plataformas; ter obtido uma missão pode ajudar a obter outras, melhores ou mais bem pagas. Alegando ter 2.000 jornalistas selecionados em 150 países, "prontos para serem contratados com um clique", a PayDesk paga aos repórteres por trabalhos concluídos para os seus clientes. Sediado em Nova Iorque, o Storyhunter utiliza algoritmos para combinar necessidades dos editores e ideias para histórias de 3.500 cinegrafistas e documentaristas. Editores e jornalistas avaliam uns com os outros as suas experiências após a sua conclusão, divulgando o que correu mal e bem. O Storyhunter também trata de pagamentos e oferece serviços editoriais. De acordo com uma história (Dyer, 2014), providenciou seguro médico aos freelancers que trabalharam sob a sua intermediação, ainda que o seu website atual não o mencione. A organização sem fins lucrativos Associated Reporters
Abroad (ARA) é um grupo alemão de freelancers profissionais (encartados) dispersos pelo mundo; possui funcionários, em regime parcial e integral, que fornecem orientação editorial, serviços de edição e apoio aos repórteres-membros no desempenho das suas missões.

\section{Utilizadores jornalistas}

Outra alternativa provém dos blogueiros locais. Os premiados blogues em árabe, inglês e francês sobre os massacres do governo tunisino de Lina Ben Mhenni têm sido utilizados por ativistas tunisianos e meios de comunicação internacionais. Uma das poucas blogueiras a utilizar o seu verdadeiro nome, Mhenni continua a ser uma proeminente blogueira e ativista da democracia na Tunísia; ativismo que, diz, lhe ter granjeado ameaças de morte. No Iraque, Salam Pax (um pseudónimo) descreveu no seu blogue o início da guerra; aparentemente, os seus materiais foram e são usados por meios de comunicação de todo o mundo (incluindo imagens e mapas), e inspiram outros iraquianos a participar na blogosfera. Ansgard Heinrich (2011) dá conta de blogueiros iraquianos cujas perspetivas não foram narradas por correspondentes estrangeiros e que, essencialmente, permitiriam que os iraquianos explicassem a vida do dia-a-dia no Iraque a partir das suas próprias vozes. Heinrich descreve Riverbend, outro pseudónimo usado por um blogueiro, como autor de relatos com um tom pessoal que contende com o ideal jornalístico da "neutralidade" ou "factualidade". Um dos entrevistados considerou Riverbend uma voz legítima e importante da comunidade. Mas acrescentou que, quando rotulado de blogueiro, "de repente, deixa de ter a credibilidade de alguém que possa efetivamente ter estado errado em relação a tudo o que fez" (Heinrich, 2011, p. 201).

Dado o intenso nível de ativismo e paixão atribuído aos blogueiros locais - e o perigo que o acompanha -, uma segunda alternativa pode corresponder aos jornalistas cidadãos que, essencialmente, produzem relatos a partir do conforto do lar. $\mathrm{O}$ facto de o acesso à internet estar disponível mesmo em zonas de guerra significa que as informações 
Several start-ups have emerged - some lasting longer than others that enable 21st century freelancers and news outlets to find each other. Most of the new businesses were backed by venture capital and were run for profit. NewsFixed and GRNlive, both now called PayDesk, are match-makers between TV and radio outlets and freelancers, who typically assume the cost and risk of going abroad. Working for multiple services may help freelancers repackage reports for multiple venues; having gotten one assignment may help get other, better or better-paying, assignments. PayDesk claims to have 2000 vetted journalists in 150 countries "ready to be hired in one click" and it pays the reporters for jobs completed for its clients. New York-based Storyhunter uses algorithms to match editors' needs and story ideas from 3,500 videographers and documentary filmmakers. Editors and journalists rate their experiences with each other after they have completed projects, letting others know what went well or not. Storyhunter also arranges payments and offers editorial services. According to one story (Dyer, 2014) it provided medical insurance to free-lancers while working on stories it commissioned, but its current website does not mention this. The nonprofit Associated Reporters Abroad is a Germany-based group of professional (vetted) freelancers around the world; full- and part-time ARA staffers provide editorial guidance, copy editing and help member reporters craft pitches to clients.

\section{Netizen journalists}

Another alternative comes from local bloggers. Lina Ben Mhenni’s prize-winning blogs in Arabic, English, and French about Tunisian government massacres have been used by Tunisian activists and international media. One of the few bloggers to use her real name, Mhenni was continues to be a prominent blogger and democracy activist in Tunisia; and she says her activism has led to death threats against her. In Iraq, Salam Pax (a pseudonym) described the start of war in his blog; apparently not only did news media around the world use his materials (which included pictures and maps), he inspired other Iraqis to blog.
Ansgard Heinrich (2011) mentions Iraqi bloggers whose perspectives were not reported by foreign correspondents and who essentially allowed Iraqis to explain day-to-day life in Iraq in their own voices. Heinrich describes Riverbend, another pseudonymous blogger, as having a personal tone that collided with the journalistic ideal of 'neutral' or 'factual' reporting. One interviewee called Riverbend a legitimate and important voice of the community, but added that when labeled a blogger, “suddenly she doesn't have the credibility of somebody else who may in fact have been wrong about everything he's done" (Heinrich, 2011, p. 201).

Given the intense level of activism and passion associated with local bloggers - and the danger attendant to that - second option might be citizen journalists who essentially report from the comfort of home. The fact that Internet access is available even in war zones means that detailed, ground-level information on the war can be posted and then analyzed by far-away citizens. In 2014, some of the most influential reports on the war in Syria were produced by two men based in England, using social media and technological 
e detalhes sobre o que se passa no terreno podem ser postados e analisados por cidadãos a distância. Em 2014, alguns dos mais influentes relatos sobre a guerra na Síria foram produzidos em Inglaterra por dois homens, que usaram media sociais e avanços tecnológicos (Platt, 2014). Os meios de comunicação tradicionais e as agências governamentais ocidentais citaram, com frequência, o trabalho de Rami Abdul Rahman, um sírio que chegou ao Reino Unido em 2000 e dirige, a partir da sua casa, em Coventry, um serviço de informações chamado de Observatório Sírio dos Direitos Humanos (Bricker, Platt, 2014). Abdul Rahman e os seus principais contatos na Síria recolhem informações de mais de 230 ativistas. $\mathrm{O}$ trabalho do Observatório tem sido, em todo o caso, contestado. Outros bancos de dados trazem à luz do dia informações diferentes. Mas muitas notícias disseminadas por organizações noticiosas também são alvo de disputa.

A Eliot Higgins, um jornalista cidadão e blogueiro que trabalha em casa, em Leicester, foi atribuída a sinalização de grandes acontecimentos na Síria, tais como o uso de bombas de fragmentação e barris de bombas pelo governo do presidente Bashar Assad. Usando o pseudónimo Brown Moses, Higgins não tinha nenhum conhecimento prévio da Síria ou contatos no terreno. Depois de uma bem-sucedida campanha de crowdfunding, lançou em 2014 a sua "investigação cidadã de fonte aberta" em tempo integral e Bellingcat [agência de jornalismo cidadão]. ${ }^{4}$ Os seus jornalistas cidadãos recorrem a vídeos do YouTube, Google Earth e outros mapas e imagens de acesso aberto, vídeos do Facebook e posts do Instagram para investigar minuciosamente (mas sem viagens) uma variedade de assuntos em todo o mundo, sobretudo relacionados com conflitos e corrupção. Tal como Higgins admite, a Bellingcat não pode substituir os repórteres no terreno. Mas os cidadãos que usam a enorme quantidade de informação disponível oriunda de grupos armados da oposição e organizações de media podem ajudar os jornalistas (Platt, 2014). A título de exemplo, um post

4 https://www.bellingcat.com/ detalhado explicou como, três dias após os ataques terroristas em Paris, os investigadores da Bellingcat identificaram um dos suicidas, usando o seu perfil no Facebook. Disponibilizada no website da Bellingcat, a informação é partilhada com governos nacionais e organizações de notícias. Higgins orgulha-se de os hackers russos o perseguirem incansavelmente nos media sociais e de os meios de comunicação controlados pelo Kremlin o denunciarem com frequência.

Os escritores da Bellingcat publicaram uma variedade de guias técnicos, aparentemente destinados, tal como os estudos de caso, a auxiliar as pessoas que procuram conduzir as suas próprias investigações sobre os problemas no mundo. Em 2016, Aric Toler, que trabalha para a Bellingcat desde 2015, publicou um artigo: "Como descobrir a corrupção usando a investigação de fonte aberta". Toler admitiu que nenhum guia único ajudará do mesmo modo todos os bancos de dados, pois estes diferem em eficácia, facilidade de uso, acessibilidade linguística, entre outros fatores. Todavia, mostrou como 
advances (Platt, 2014). Mainstream media outlets and Western government agencies frequently cited reports by Rami Abdul Rahman, a Syrian who came to the U.K. in 2000 and runs an information service called the Syrian Observatory of Human Rights from his home in Coventry (Bricker, 2013; Platt, 2014). Abdul Rahman and his main contacts in Syria collate information from more than 230 activists. The Observatory's work has been disputed. Other databases come up with different figures. But many legacy news outlets produce reports are also disputed.

Eliot Higgins, a citizen journalist and blogger who works from his home in Leicester, was credited with detecting major developments in Syria, such as the use of cluster bombs and barrel bombs by President Bashar Assad's government. Using the pseudonym Brown Moses, Higgins had no prior knowledge of Syria or contacts on the ground. After a successful crowd-funding campaign, his "citizen open source investigation" full-time and Bellingcat (https://www.bellingcat.com/) launched in 2014. Its citizen journalists use YouTube videos, Google Earth and other maps

\section{Bellingcat writers}

have posted a

variety of technical

guides, apparently

intended, with the

case studies, as

helpful to people

looking to do their

own investigation

of problems

around the world and pictures, open source data, Facebook video, and Instagram posts to painstakingly (but without travel) investigate a variety of subjects, primarily corruption and conflicts across the world. Bellingcat cannot replace reporters on the ground, as Higgins admits, but citizens using the huge amount of information available from armed opposition groups and media groups can help journalists (Platt, 2014). For example, a detailed post explained how, three days after the terrorist attacks in Paris, Bellingcat investigators identified one of the suicide bombers by using his Facebook profile. The information is posted on Bellingcat's site and shared with national governments and news organizations. Higgins boasts that Russian bots troll him relentlessly on social media, and Kremlin-controlled media outlets frequently denounce him.

Bellingcat writers have posted a variety of technical guides, apparently intended, with the case studies, as helpful to people looking to do their own investigation of problems around the world. In 2016, Aric Toler, who has worked for Bellingcat since 2015, posted an article, "How to Uncover 
se podem usar vários recursos de pesquisa - registos de empresas, tribunais, registos judiciais, artigos de notícias, Wikileaks de Departamentos de Estado e outras bases de dados. Deve, de qualquer modo, realçar-se que a investigação e métodos da Bellingcat têm sido desafiados. Por exemplo, a agência ofereceu o que alegou ser a prova de o Ministério da Defesa da Rússia ter alterado digitalmente imagens de satélite para esconder como um lançador de mísseis russo, operado pelo país, derrubou um avião da Malaysia Airlines, no leste da Ucrânia. Acontece que um especialista alemão em imagens forenses (apud Bidder, 2015) criticou o método de Análise do Nível de Erros da Bellingcat, considerando-o "subjetivo e não baseado inteiramente na ciência". Um artigo da New Republic coloca, no entanto, a Bellingcat na categoria "muito confiável". Outros agregadores de notícias, tais como a Rede de Notícias Shaam, sediada em Damasco, e o Centro de Media de Alepo, são vistos como sendo igualmente rápidos, mas apenas "parcialmente confiáveis" (Caplan-Bricker, 2013).

\section{Conclusão}

A guerra na Síria coloca todos estes problemas em foco. O CPJ atribui à Síria o terceiro lugar (depois da Eritreia e da Coreia do Norte) na lista dos países com a pior censura. O governo impôs severas restrições aos meios de comunicação e proibiu efetivamente a entrada da imprensa internacional no território. De acordo com o CPJ, o regime de Assad impôs um apagão na cobertura de notícias independentes, impediu os repórteres estrangeiros de entrarem e relatarem livremente os acontecimentos e deteve e atacou jornalistas locais considerados desfavoráveis (isto é, os que tentaram cobrir protestos). $\mathrm{O}$ governo desativou os telefones e a internet dos repórteres, torturou jornalistas para extrair senhas de entrada em media sociais e encorajou ataques de malware contra estes profissionais. $\mathrm{O}$ facto de alguns partidários estrangeiros terem entrado na Síria afirmando ser jornalistas também colocou em perigo os jornalistas profissionais.

Além da censura, o regime de Assad tem sido implicado no desaparecimento ou morte de jornalistas. Ferzat
Jarban, por exemplo, um repórter de imagem sírio, foi preso depois de ter documentado protestos contra Assad. O seu corpo foi encontrado com sinais de mutilação. Mais de 80 jornalistas foram sequestrados na Síria - cerca de 20 continuam desaparecidos - por uma multiplicidade de razões, incluindo por contrapartidas financeiras pelo seu resgate. Pelo menos 70 jornalistas, quase metade deles freelancers, foram mortos desde 2011, segundo o CPJ. Os mortos ou desaparecidos são sobretudo sírios.

Isto deixa de fora os jornalistas cidadãos, na sua maioria ativistas, que apoiam a oposição. Isto apesar de, recentemente, de acordo com a Amnistia Internacional, as forças da oposição transformarem jornalistas profissionais e cidadãos em alvos, dependendo da sua política. Soazig Dollet, da RSF, afirma: "Para cobrir o conflito, não há outra escolha senão a dos jornalistas cidadãos para tornar as imagens públicas .... Mas isso não significa que o conflito seja devidamente noticiado: tanto as autoridades como os grupos armados da oposição espalham desinformação. E apesar do surgimento dos media-cidadãos geralmente pró-revolução - há muito 
Corruption Using Open Source Research." Toler admitted that no single guide would help with every database, as these differ in effectiveness, ease of use, language accessibility, and other factors. But he showed how one might use various investigative resources - business registries, land tribunals, court registries, news articles, Wikileaks of State Department Cables, and other databases.

Bellingcat's research and methods have been challenged, it should be noted. For example, Bellingcat offered what it claimed was proof that Russia's Defense Ministry digitally altered satellite images to hide how a Russian-supplied, Russian-operated missile launcher shot down a Malaysia Airlines plane in eastern Ukraine. But a German image forensics expert (quoted in Bidder, 2015) criticized Bellingcat's Error Level Analysis method as "subjective and not based entirely on science." A New Republic article put Bellingcat in the "very reliable" category but it described other news aggregators, such as the Damascus-based Shaam News Network and the Aleppo Media Center, as quick to post but only "partially reliable" (Caplan-Bricker 2013).

\section{Conclusion}

The war in Syria brings all these problems into focus. The CPJ lists Syria third (after Eritrea and North Korea) as having the worst censorship. The government has placed stringent restrictions on media and has effectively banned entry to almost all international press. According to the CPJ the Assad regime has imposed a blackout on independent news coverage, barred foreign reporters from entering and reporting freely, and detained and attacked local journalists who it regards as unfavorable (that is, trying to cover protests). The government has disabled reporters' phones and the Internet, tortured journalists to extract passwords of social media sites, and encouraged malware attacks against journalists. The fact that some foreigner partisans have entered Syria by claiming to be journalists has also endangered professional journalists.

Beyond censorship, the Assad regime has been implicated in the disappearance or deaths of journalists. Ferzat Jarban, for example, a Syrian videographer, was arrested after he documented protests against Assad.
His body turned up bearing signs of mutilation. More than 80 journalists have been kidnapped in Syria-with about 20 still missing-for a variety of reasons, including the ransom money itself. At least 70 journalists, nearly half of them freelancers, have been killed since 2011, according to the Committee to Protect Journalists (CPJ). Most those killed or who are missing have been Syrian.

This leaves freelancers and citizen journalists, nearly all of whom are activists who openly support the opposition, although, according to Amnesty International, more recently, opposition forces are also targeting professional and citizen journalists, depending on their politics. RSF's Soazig Dollet says: "In order to cover the conflict, there is no other choice than citizen journalists to get the images out.... But that does not mean the conflict is properly covered: both the authorities and armed opposition groups are spreading disinformation. And despite the emergence of citizen mediausually pro-revolution-there are very few independent observers, and a very limited number of foreign correspondents" (Caplan-Bricker-2013). 
poucos observadores independentes e um número muito limitado de correspondentes estrangeiros" (Caplan-Bricker, 2013). Na verdade, os cidadãos que cobrem a guerra que acontece à sua volta podem estar em maior perigo. A RSF calcula que, entre 2011 e 2013, $73 \%$ dos jornalistas que morreram na Síria eram cidadãos-jornalistas.

Cofundador da GlobalPost, Charles Sennott esteve também na base da criação do GroundTruth Project. Apoiado por uma série de fundações, o GroundTruth auxilia - através de financiamento e orientação - jovens repórteres que produzem jornalismo de investigação. Sennott trabalhou com 25 proeminentes organizações de notícias e grupos de interesse para gizar o documento "Princípios e Práticas de Segurança Global”. Nele são articuladas expectativas e responsabilidades partilhadas por organizações de notícias e repórteres, para que estes possam trabalhar em segurança. Previsivelmente, os jornalistas que desempenham tarefas perigosas são advertidos em matéria de cuidados e de segurança física e psicológica a necessidade de casacos blindados e capacetes, de seguro médico e de habilidades básicas de primeiros socorros. Mas são também instados a manterem-se atualizados através do recurso a formação contínua.

O "guia de campo" revisto representa um avanço. Mas o documento do GroundTruth poderia e deveria ter acrescentado que os cursos de preparação para ambientes hostis não só devem ser exigidos (e pagos por um consórcio de organizações de notícias), como devem incluir a consciencialização no que diz respeito às questões de género e aos fatores específicos de género relativos à violência sexual e à possibilidade de sofrer de desordens de stress pós-traumático decorrentes de assédio, ataques sexuais e violações; e as mulheres não são menos relutantes em admitir a doença do que os homens. Atualmente, os instrutores não ensinam nada sobre a violação ou como minimizá-la, o que fazer uma vez vítima ou quais os recursos disponíveis. Além disso, as repórteres mulheres são desencorajadas de discutir estas questões com os seus editores ou mesmo com os seus colegas. Uma representante de uma empresa de segurança privada sustentou que a sua corporação começou por incluir a agressão sexual no seu treino, mas acabou por abandonar o tema, porque os homens se mostraram desconfortáveis com ele (Dart Center, 2005). Na verdade, talvez as mulheres devessem ministrar estes cursos.

Acresce também que o GroundTruth pode estar simplesmente a pregar um sermão, ao incitar os jornalistas que trabalham em zonas de conflito a trabalhar com os colegas na avaliação dos riscos, antes de viajarem para ambiente hostis ou perigosos. Os freelancers jovens, inexperientes e empobrecidos, e os cidadãos-jornalistas não compreenderão a sua vulnerabilidade e não lerão o guia de campo. Do mesmo modo, não irão comprar a roupa de proteção e munir-se de kits de primeiros socorros, se os puderem pagar. Janine di Giovanni (2014) observou que, quando foi para Sarajevo, em 1992, quando era uma jovem e idealista repórter, o que aprendeu sobre segurança foi com a má sorte dos outros: "O treino era rudimentar e autodidata: de tentativa e erro". Além disso, quando começou a cobrir a Síria, em 2011, comofreelancer, foi capaz de exigir um contrato e seguro de guerra. Valorizou 
Indeed, the citizens who report on the war going on around them may be most in danger. Between 2011 and 2013, RSF estimated that 73 per cent of the journalists who have died in Syria were citizen-journalists.

Charles Sennott, a co-founder of GlobalPost, went on to found The GroundTruth Project. Backed by a number of foundations, GroundTruth supports - with funding and mentoring - young journalists doing in-depth reporting. Sennott worked with 25 prominent news organizations and advocacy groups to draft "Global Safety Principles and Practices." This articulates shared expectations and responsibilities for news organizations and reporters so that they can work safely. It certainly warns journalists on dangerous assignments about safety - the need for armored jackets and helmets, medical insurance, and basic first aid skills. It urges journalists to stay up-to-date on standards of care and physical and psychological safety through on-going training.

The revised "field guide" represents progress. But the GroundTruth guide could and should have added that hostile environment courses should not only be required (and paid for by a consortium of news organizations) but should include gender-sensitivity and gender-specific factors about sexual violence and the possibility of post-traumatic stress disorders following from sexual harassment, rape and sexual assault; and women are no less reluctant to admit PTSD than men. Trainers now teach nothing about rape or how to minimize it, what to do if raped or what resources are available to them. Moreover, women reporters are discouraged from discussing these issues with editors or even colleagues. A private security company representative said her corporation had included sexual assault in its training but dropped it because men were uncomfortable with it (Dart Center 2005). Indeed, perhaps women should teach the courses.

Moreover, GroundTruth may be preaching to the choir in urging journalists operating in conflict zones to work with colleagues to assess risks and take risks into account before traveling to any hostile or dangerous environment. Young, inexperienced impoverished freelancers and citizen-journalists won’t understand their vulnerability and won't read the field guide. They won't buy the protective clothing and carry first-aid kits, if they could afford them. Janine di Giovanni (2014) noted how when she went to Sarajevo as a young, idealistic reporter in 1992, she learned about safety from the bad fortune of others: "It was rudimentary, self-taught training: trial and error." Moreover, when she started covering Syria in 2011 as a freelancer she was able to demand a contract and war insurance. She enjoyed the backing of major news organizations - something that also became crucial to her son's father, a France 2 reporter who was shot in the jaw by a sniper in Libya. Her point was the huge "alarming" change in freelancing and new breed of freelancer, including some "who watched Hollywood films and thought the life of a war correspondent was glamorous." Putting it more strongly, James Harkin (2016) describes the new crew of freelance reporters who moved from Libya to Syria: "But while most of these new arrivals were real reporters earning their spurs, there was a worrying new development 
o apoio das grandes organizações de notícias - algo que também se tornou crucial para o pai do seu filho, o repórter da France 2 que foi baleado na mandíbula por um atirador, na Líbia. A questão que salienta é a enorme e "alarmante" mudança nas novas gerações de freelancers, incluindo aqueles "que assistiram a filmes de Hollywood e pensaram que a vida de um correspondente de guerra era glamourosa". Endurecendo ainda mais o problema, James Harkin (2016) descreve do seguinte modo a nova equipa de freelancers que se deslocaram da Líbia para a Síria: "Enquanto a maioria destes novos recém-chegados eram verdadeiros repórteres, ostentando os seus galardões, um novo e preocupante desenvolvimento estava à vista - a presença de viciados em adrenalina, aventureiros, fantasistas ou narcisistas loucos, que, em primeira instância, nunca deveriam ter estado na Líbia ou na Síria."

As novas diretrizes do GroundTruth vão mais longe do que as anteriores ao exortar as organizações de notícias que contratualizam missões em lugares perigosos a mostrarem a mesma preocupação com o bem-estar dos freelancers e jornalistas locais que demonstram relativamente aos seus funcionários e a assumir a mesma responsabilidade no caso de sequestro ou de agressões e a ter em conta os custos com a formação, seguros e equipamentos segurança. O documento do GroundTruth acrescenta que os editores devem delinear a quantia a ser paga aos freelancers e as despesas elegíveis e tentar providenciar um adiantamento ou pelo menos o célere pagamento do trabalho após a sua conclusão.

Faz sentido colocar o ónus - moral e financeiro - nas organizações de notícias, pelo que o GroundTruth poderia, de facto, ter ido mais longe. John Owen, professor de jornalismo internacional na City University, em Londres, defende que as organizações de notícias que usam material produzido por jornalistas independentes "não podem subcontratar o seu dever de cuidado e de responsabilidade moral" e não devem tentar os freelancers a perseguirem histórias de risco (apud Platt, 2014). Na verdade, nos últimos anos, os media noticiosos começaram a repensar o uso de freelancers. No Reino Unido, o The Guardian e o
Sunday Times recusaram-se a utilizar freelancers para evitar encorajar esse mercado. A Associated Press diz que só usa freelancers que tenham seguro e equipamento de proteção e que não os enviará para a Síria ou Líbia. Em 2014, o seu editor executivo declarou: "Muitos jornalistas vão até ao ramo até o ramo estar partido e o nosso trabalho é puxá-los para trás.... Dizer 'eu confio no seu julgamento’ é uma completa abdicação de responsabilidades" (apud, Hammer, 2014).

Já a questão dos jornalistas cidadãos continua a ser muito mais ambígua. Após a decapitação de Foley, o diretor de notícias da Agence France-Presse admitiu que continuaria a usar material de cidadãos sírios, mas que deixaria de aceitar fotografias ou qualquer outra contribuição de freelancers que viajassem para a Síria. Naturalmente que esta posição coloca em maior risco os repórteres locais (nacionais). Pelo menos para a Síria, di Giovanni (2014) defende um processo de acreditação, que exija que os repórteres obtenham formação e seguro adequados a ambientes hostis. A acreditação caiu, no entanto, em desuso, em parte porque foi usada 
- the presence of adrenaline-junkies, adventurers, fantasists or crazy narcissists who shouldn't have been in Libya or Syria in the first place."

GroundTruth's new guidelines go farther than the earlier ones in urging news organizations making assignments in dangerous places to show the same concern for the welfare of local journalists and freelancers that they do for staffers, to take the same responsibility for freelancers in the event of kidnap or injury as they would for staffers and to factor in the costs of their training, insurance and safety equipment. GroundTruth adds that editors should delineate what freelancers will be paid and what expenses will be covered and to try to provide an advance, or at least quickly pay for completed work.

Putting the onus-morally and financially_on news organizations certainly makes sense, so again, GroundTruth could have gone further. John Owen, Professor of International News at City University in London, says that news organizations using freelance material “can't contract out their duty of care and moral responsibility" and should
Putting the onus

- morally and

financially -

on news

organizations

certainly makes

sense, so again,

GroundTruth

could have

gone further not tempt freelancers into pursuing risky stories (quoted in Platt, 2014). In recent years, news organizations have begun to rethink using freelancers. In the UK, the Guardian and the Sunday Times have declined to use freelancers to avoid encouraging that market. The Associated Press says it only uses vetted freelancers who have insurance and protective gear, and won't send them to Syria or Libya. Its executive editor said in 2014: "Plenty of journalists go out on the branch until the branch is cracked, and our job is to pull them back... To say 'I trust their judgment' is a complete abdication of responsibility" (quoted in Hammer 2014).

The issue of citizen journalists remains far more ambiguous. After Foley's beheading, the news director of Agence France-Presse said it would continue to use material from Syrian nationals but stopped accepting photos or any other contributions from freelancers who travel into Syria. But this, of course, puts at even greater risk local reporters (nationals), who remain at the greatest risk. At least for Syria, di Giovanni (2014) 
para excluir certo tipo de jornalistas (especialmente mulheres). Portanto, esta pode não ser uma solução de primeira linha.

Acresce que as organizações de notícias deveriam contribuir para um fundo a que todos os jornalistas de guerra - em tempo integral, freelancers ou cidadãos - e seus cuidadores pudessem aceder em caso de serem feridos, sequestrados ou necessitarem de terapia. $\mathrm{O}$ objetivo, claro está, é minimizar a probabilidade de isso acontecer. Vários jornalistas europeus mantidos como reféns foram libertados depois de os seus governos terem pago secretamente resgates, através de intermediários. Os resgates estão a aumentar precipitadamente à medida que o sequestro de europeus se transformou num negócio global para a Al Qaeda, financiando as suas operações em todo o globo: entre 2008 e 2015, a Al Qaeda e as suas afiliadas obtiveram pelo menos US\$ 125 milhões em sequestros - oriundos principalmente de governos europeus (Callimachi, 2014). Embora os EUA ainda não paguem resgates por reféns (porque, em teoria, fazê-lo encoraja mais sequestros e financia o terrorismo), a orientação política atual é a de não processar pessoas que o façam. Mas alguns jornalistas podem efetivamente ser sequestrados, apesar de tudo fazerem para o evitar, à exceção de permanecer em casa. Se tal acontecer, a sua libertação não pode ficar dependente de um filantropo, mas deve ser da responsabilidade coletiva dos meios de comunicação.

$\mathrm{O}$ trabalho em rede parece ser a melhor esperança. Certamente as organizações de notícias podem formar consórcios e outras parcerias, com vista a partilhar antecipadamente os custos decorrentes de providenciar seguros, treino, equipamento de proteção e até mesmo pessoal de segurança. Ou seja, além de acordarem usar apenas material fornecido por repórteres que minimizam os riscos a que estão sujeitos, as organizações jornalísticas deverão pagar pelas diversas ferramentas e processos disponíveis para reduzir a perigosidade das missões. Refiro-me não apenas a meios de comunicação participativos e integradores, que permitam que as pessoas "se envolvam" no jornalismo, mas também que que incentivem a colaboração entre plataformas e organizações de notícias. Reconstrutores, cidadãos, repórteres, ativistas, todos têm as suas redes específicas, que se estendem através de múltiplos nós e alcançam tamanhos variados. Se, como defende Heinrich (2014), o desenvolvimento de ligações estáveis e contínuas com os emergentes provedores alternativos de notícias irá globalizar o jornalismo, a verdade é que as exigências e as urgências da guerra exigem redes interconectadas e interativas mais robustas. 
advocates an accreditation process, one requiring reporters to have insurance and hostile environment training. Accreditation has fallen out of favor, in part because it was used to exclude certain kinds of journalists (especially women). So this may be a non-starter.

Moreover, news organizations should contribute to a fund that all war journalists - full-time, freelancer, citizen - and their fixers could draw upon if they are injured or kidnapped, or need therapy. The goal, of course, is to minimize the likelihood in the first place. Several European journalists held hostage have been freed after their governments secretly paid ransoms through intermediaries. Ransoms are rising precipitously as kidnapping Europeans for ransom has become a global business for Al Qaeda, bankrolling its operations across the globe: Al Qaeda and its affiliates got at least $\$ 125$ million from kidnappings between 2008 and 2015 - primarily from European governments (Callimachi, 2014). Although the U.S. still will not pay ransom for hostages (on the theory that this merely encourages more kidnapping and funds terrorism), U.S. policy now holds that people who pay ransom to free hostages will not be prosecuted. But some journalists may be kidnapped despite doing everything possible to avoid it, short of staying home. Securing their release should not depend on one philanthropist, but should be the collective responsibility of news outlets.

Networking seems the best hope. Certainly news organizations can form consortia and other partnerships such that news organizations would share upfront in the costs of providing insurance, training, protective gear, and even security personnel. That is, besides agreeing to use material providing by reporters only if they have minimized the risk, news organizations should pay for the various tools and processes available for minimizing that risk. Here I mean not only a integrating participatory media into journalism in ways that fully allow people to "engage" in reporting but also encouraging collaboration across platforms and news organizations. Fixers, citizens, reporters, activists all have their separate networks, extending out through multiple and variously-sized nodes. If, as Heinrich (2014) says, developing stable and continuous links with emerging alternative news providers will globalize journalism, the exigencies and urgencies of war call for more robust intersecting, interactive networks. 


\section{Bibliografia/ References}

Bidder, B. (2015). 'Bellingcat Report doesn't prove anything': Expert criticizes allegations of russian MH17 manipulation. Spiegel Online International. Acedido a 12 de julho de 2016, em http://bit.ly/2dHKidD.

Callimachi, R. (2014). Paying ransoms, Europe bankrolls Qaeda terror. New York Times. Acedido a 12 de julho de 2016, em http://nyti.ms/UJnpqH.

Caplan-Bricker, N. (2013). Guide to Syria's best citizen journalism. The New Republic. Acedido a 12 de julho de 2016, em http://bit.ly/2cR13N6.
Chadha, K. \& Steiner, L. (2015). The Potential and limitations of citizen journalism initiatives: Chhattisgarh's CGNet Swara. Journalism Studies, 16(5), 706-718.

Colvin, M. (2012). Our mission is to report these horrors of war with accuracy and without prejudice. The Guardian. Acedido a $12 \mathrm{de}$ julho de 2016, em http://bit.ly/ 2dHDwQC.

Dart Center (2005). Women Reporting War. Acedido a 12 de julho de 2016, em http://bit.ly/2d4764v.

di Giovanni, J. (2014). The education of a foreign correspondent. Neiman
Reports. Acedido a 12 de julho de 2016, em http://bit.ly/1x913Rq.

Dyer, J. (2014). A new generation of correspondents hustles for work with the help of the Web. Neiman Reports. Acedido a 12 de julho de 2016, em http://bit.ly/1Azheor.

Gladstone, R. \& Callimachi, R. (2016). American who vanished in Syria almost four years ago is released, Official Says. New York Times, A6.

Hammer, J. (2014). As legacy news outlets retreat, Who will be There to report on the world? Nieman Reports. Acedido a 12 de julho de 2016, em http://bit.ly/1zpQG9D. 
Harkin, J. (2016). Kevin Dawes: Searching for a missing American in Syria. GQ. Acedido a 12 de julho de 2016, em http://bit.ly/1Yj4qhA.

Heinrich, A. (2011). Network jkournalism: Journalistic practice in interactive spheres. New York: Routledge.

Jones, G. E. (2013). Hidden world of south Sudan: An interview with photojournalist Camille Lepage. PetaPixel. Acedido a 12 de julho de 2016, em http://bit.ly/lgksAI7.

Mnookin, S. (2008). The New York Times's lonely war. Vanity Fair. Acedido a 12 de julho de 2016, em http://bit. ly/2dt193a.
Platt, E. (2014). Citizen journalists playing a crucial role in Syrian War. Time. Acedido a 12 de julho de 2016, em http://ti.me/1vR4Yxt.

Schwartz, Y. (2016). Vice shows how not to treat freelancers. Columbia Journalism Review. Acedido a 12 de julho de 2016, em http://www.cjr.org/ the_feature/vice_freelancers.php.

Watts, J. (2013). Brazil's ninja reporters spread stories from the streets. The Guardian. Acedido a 12 de julho de 2016, em http://bit.ly/2dHDsQE.

Wente, M. (2013). Amanda Lindhout, innocent abroad - and recklessly naïve. The Globe and Mail. Acedido a 12 de julho de 2016, em http:// bit.ly/2cRlerQ.

Yazid, R. M. (2014). Citizen journalism in a war zone. Asia-Pacific Media Update. Acedido a 12 de julho de 2016, em http://bit.ly/2dZgo34. 